\title{
The evaluation of the relationship between firms information quality with loans accreditation Iranian bank
}

\author{
Hassan Ghodrati ${ }^{\mathrm{a}}$ and Ramin Nouri*
}

Accounting \& Management Department, Kashan Branch, Islamic Azad University, Kashan, Iran

\begin{tabular}{l}
\hline C H R O N I C L E \\
\hline Article history: \\
Received October 1, 2012 \\
Received in revised format \\
5 February 2012 \\
Accepted 7 February 2013 \\
Available online \\
February 82013 \\
\hline Keywords: \\
Components of Accounting \\
Information Quality \\
Accreditation of Loans \\
Bank Contracts
\end{tabular}

\section{A B S T R A C T}

\begin{abstract}
This research aims to study the effects of the quality of financial information companies on the accreditation of loans and bank contracts of the branches of Bank Mellat in the East Azerbaijan province. This is an applied research using 67 branches of Bank Mellat of the East Azerbaijan province. The study chooses a sample of 31 branches to evaluate the effects of the quality of financial information companies on the accreditation of loans and bank contracts. There are variables associated with quality of financial information such as their relevance, timeliness, and reliability over the period 2010-2011 using multi-variables linear-regression technique. The results of this study show that relevance, timeliness, and reliability variables are effective on the accreditation of loans and bank contracts of the branches.
\end{abstract}

(C) 2013 Growing Science Ltd. All rights reserved.

\section{Introduction}

Today, banking system plays an essential role in economy and they collect small and large amounts of capitals of individuals, households, and institutes, on the one hand, and provide loans to business owners on the other hand to pave the way for the economic growth. However, this will happen only if legal relationships, tools and techniques of the relationships between banks and their customers, whether depositors or applicants for facilities are reasonable, efficient, and well proportioned to create motivations for cooperation. After recent modification on Iranian banking law and deletion of loans and credits granted as debt with interest, other methods have also been provided for the allocation of sources classified in into four general groups including interest-free loans, exchange contracts, partnership contract, and direct investment. 
To make economic decisions, one needs some sorts of information implemented for the appropriate allocation of the existing and available resources. As a result, the methods of having access to information and quality value are considerably important for decision-making. The lack of information or presence of misleading information could cause improper economic decisions to be made, therefore, economic sources are lost, capital markets are depressed, which leads societies towards underdeveloped, economically poor with poor public welfare. Therefore, valid understandable and relevant information is regarded as one of the main tools for the economic development of a country.

One of the fundamental prerequisites for winning the trust of investors and creditors for economic constructive activities and as a result economic upturn is the availability of sufficient financial information for making appropriate decisions on the sales and purchase of shares, evaluation of managerial performance, accountability of directors, as well as the grant of credit to the economic enterprises. This helps governments make appropriate planning for economic affairs and management and supervision of the activities of economic enterprises. The investors, who use more accounting information, can make better and more rational decisions.

Ambiguous information of firms increases the costs paid by banks for the recognition and supervision required for granting facilities. Previous investigations have shown that financial information is effective in pricing loans. The financial information of firms is the outputs of their accounting system, whose success depends on whether accounting information, can improve the decisions made by the directors of such firms. However, this is not the only the provision of information, which could improve the process of decision-making. If accounting system fails to provide sufficient information required for the management, the decisions made by the directors would not be efficient.

This research aims to study the effectiveness of the quality of the financial information required by banks in the evaluation of companies for granting loans and facilities as well as concluding contracts with banks. Moreover, we aim to answer the question of which relation exists between the quality of financial information of companies and the accreditation of loans and bank contracts.

\section{Literature Review}

Financial reports are the primary sources for obtaining information and making financial or legal decision making. The objectives of financial reporting and principles of accounting are involved with the cultural, political, social, and economic circumstances as well as legal relationships with the related societies. In addition, the data collected for making decisions and judgments by beneficiaries must be suitable, reliable, and relatively correct for the related business units. Accounting literature consists of the studies conducted on the different aspects of the quality of accounting information. Although there is no consensus on the concept of accounting quality, some aspects of this concept have been operationalized. These studies have developed in general some criteria of quality using reported profit and profit components terms as "quality of earnings" and "accruals".

Twenty years after the enforcement of interest-free banking act in Iranian economy, we may need to make an assessment on the performance of this banking system. There are two important characteristics associated with banking system, which are the method of granting of facilities and allocation resources. The new regulations in Iranian banking law try to prohibit granting interestbearing loans and credits. Therefore, there are other methods of resources allocation including interest-free loans, exchange contracts, including installment sale, hire purchase, forward purchasing, reward contract, and factoring, partnership contracts, civil partnership, legal partnership, limited partnership, agriculture contract, and gardening contract, and direct investment. The study of these methods show that only exchange contracts are compatible with the nature of trade banks as well as the objectives and interests of the applicants for bank facilities. Therefore, if banks' customers are required to enter into other types of contracts, the resources of trade banks are lost and the conclusion of such contracts are considered only of formality nature. The practical study of exchange contracts shows that these types of contracts are not able solely to meet the whole needs of the applicants of the 
trade bank facilities. Another problem is the approach of granting such facilities. In addition to the common methods of borrowing loans and credits, the global banking system uses the method of granting facilities by credit in current account and credit cards, which are in the interest of both banks and customers. Practical study of exchange contracts show that these types of contracts are suitable for granting facilities not only based on conventional methods, but also by credit in current account and credit cards.

\subsection{Benefits of Using Performance Pricing Debts}

Recent studies have pointed out some benefits of using performance pricing debt. First, Asquith et al. (2011) suggested that interest-decreasing performance pricing provisions are more likely suitable when the probability of prepayment is higher and expected renegotiating costs are larger. Interestincreasing performance pricing provisions are likely when there is a higher chance of adverse selection and moral hazard problems associated with the borrower (Asquith et al., 2005). Another advantage of performance pricing is pointed out in theoretical work by Manso et al. (2006). They suggested that this method could mitigate moral hazard problems and argued that performance pricing could lead to a higher interest rate when cash flows were lower, which in turn could increase the likelihood of default. The resulting threat of losing control over the project induces the manager not to extract cash flow from the firm for personal implementation.

In addition, Tchistyi (2011) shows that a scheme that punishes bad performance with higher interest rates could provide additional incentives for the manager to exert effort. Asquith et al. (2011) provided some empirical evidence that firms with a higher probability of moral hazard are more likely to include interest increasing performance pricing in their bank loan contracts. Third, performance pricing could be implemented as a signaling and screening device in the presence of asymmetric information.

Manso et al. (2010) developed a model where the future prospects of the firm are unknown to the market, but known to the manager or equity holders. A manager who is optimistic about the firm's future prospects, high-growth firm, will issue debt with performance pricing as a signal of quality, while a manager who is pessimistic about firm's future prospect, low-growth firm, will issue equity or fixed-interest debt. The low-growth firm cannot mimic the high-growth firm because for a given performance pricing debt, it would likely pay higher interest in the future than the high-growth business unit if the actual type of the firm is disclosed. Consistent with this idea, Manso et al. (2010) reported that firms choosing performance pricing loans would more likely to improve their credit ratings than firms choosing fixed-interest loans.

\subsection{Costs of Using Performance Pricing Debts}

While the studies mentioned above discuss the benefits of adopting performance pricing provisions, there is a little discussion associated with the costs of such provisions. Below, we discuss some potential costs of performance pricing and the implications for the characteristics of borrowers and lenders that enter into loan agreements with performance pricing.

There are literally various studies on this issue and the studies of the effects of different factors on the volume of bank contracts and their accreditation have yielded various results. Some of these studies are focused on the factors effective in the nonpayment of the granted loans. In addition, other studies are focused on the failure in the correct accreditation of contracts, and the ability to repay debts by forecasting the financial performance of companies. Altman et al. (1968) studied 80 financially successful or insolvent companies in the USA and introduced five factors as follows,

1. The ratio of retained earnings to total assets,

2. The ratio of working capital to total assets, 
3. The ratio of earnings before interest and taxes to total assets,

4. Market value of equity to total liabilities,

5. The ratio of sales to total assets as the most important factors that distinguishes financially successful companies and bankrupted ones.

Manso et al. (2010) developed a model, in which the directors informed of the perspective of their companies and evaluate it pessimistically, introduce the performance of accreditation and debt as quality tools. According to another study, directors prevent the breach of debt obligation by abnormal accruals. According to another research, the borrower providing most ambiguous information causes pricing regulations to be less involved in loan contracts. In case a loan is granted by bank to a loanee, the costs of supervisions should be reduced.

Beatty and Weber (2003) conducted a study on the effects of supervision and personal information on the role of accounting quality in decision-making. The results of their studies demonstrated that accounting quality could be reduced if banks could only access to only personal information of financial companies and capital costs would be limited. Moreover, if the asymmetry of information causes great difficulties, quality of accounting information will be of great importance.

In another study conducted by Jiang (2009), it was shown that income accounting and liquidity flows were fully associated with share price. After all, it is cleared that the relationships between liquidity flow and share price are of more significance, and liquidity flows are informatively of higher quality. According to Wittenberg-Moerman (2008), supervision costs of the quality of accounting information of the borrowers might be reduced, and the regulations of pricing might be less subject to the loan contracts, if the accounting information of the borrower was of lower quality and usually heavy penalties are imposed in cases of false recounting in companies.

In another research conducted by Kousenidis et al. (2009), it was demonstrated that,

1- There is a nonlinear relationship between conservative reporting and the relevance of earnings.

2- Such relevance is increased in semi-conservative firms in comparison with the less conservative ones and it increases in most conservative enterprises.

3- In conclusion, the results of this research supports the theoretical fundamentals of Watts (2003) that provide the arguments supporting conservativeness on the one hand, and question the application of extreme conservative reporting, which may distort potentially the relation between earnings and return.

Sufi (2007) reported that if there were limited information about a borrower, lead banks would choose syndicate participants, which would are more likely to "know" the borrower through previous lending relationships. Therefore, a prior lending relationship potentially could reduce monitoring costs. As a result, performance pricing is more likely to be included in a loan contract when there is a stronger prior lending relationship between the borrower and the bank.

Chaney et al. (2011) showed that the decisions made by the beneficiaries of accounting information depend on the quality of information and argued that relative balance between reliability and relevance of information are two important characteristics played an essential role in the emergence of Internet. While internet-based financial reporting increases the domain of information including content, time, and manner of the dissemination of information, and relevance of information, specifically the issue of timeliness, it may increase the risks of unreliable information as well. Moreover, failure in auditing and insecurity of websites are the other reasons of decrease in reliability. Internet-based financial reporting enables firms to increase their financial disclosures by disclosing additional and separated financial data in their websites (Ashbaugh-Skaife et al., 2008).

Some studies show that the risk of accruals quality is priced statistically and economically after separating shares with lower price. Kohlbeck (2008) stated that the increase in accounting quality 
could influence the view of analysts and investors In conclusion, their evidences for a generalized concluding were different. For example, the coefficients of earnings reactions, accruals quality based on balance sheet approach, and explanatory power of evaluation models were reduced.

\section{Research Hypotheses}

\section{Main Hypothesis:}

There is a relationship among the quality of financial information of companies and the amounts of loans and bank contracts of the different branches of Bank Mellat in the East Azerbaijan Province.

\section{Sub-Hypotheses:}

Our hypotheses research is as follows:

1-There is a relationship between the relevance of financial information of companies and the amounts of the granted loans and bank contracts.

2- There is a relationship between the timeliness of financial information of companies and the amounts of the granted loans and bank contracts.

3- There is a relationship between the reliability of financial information of companies and the amounts of the granted loans and bank contracts.

\section{Research Methodology}

This is an applied research in terms of objective, and it uses a descriptive-analytic method for inference.

\subsection{Statistical Population and Sample}

The statistical population of this research consists of all 67 branches of Bank Mellat in the East Azerbaijan province. For taking samples, simple randomized sampling method has been applied. For this purpose, a pilot sample was taken randomly, and the variance of the samples (where, $\mathrm{N}=67$ and $\mathrm{t}=2.25$ ) was determined equal to 0.43 , and the accuracy level ( $\varepsilon$ ) equal to 0.2 . Accordingly, the number of the members of the statistical samples was equal to 31 branches.

\subsection{The Methods of Data Analysis}

This research, which is an applied one in terms of its objectives, and uses descriptive-analytical method for inference, applies the ex post facto method for the collection of data. For induction, distribution of frequency, graphs, and calculation of indices are used. Moreover, to analyze the relation between variables, linear regression is used.

\subsection{Research Models}

The following models are used to test the hypotheses of regression:

Model of Relevance: 
$\operatorname{RET}_{\mathrm{j}, \mathrm{t}}=\beta_{0, \mathrm{j}}+\beta_{1, \mathrm{j}}+\mathrm{E}_{\mathrm{j}, \mathrm{t}}+\beta_{2, \mathrm{j}} \Lambda \mathrm{E}_{\mathrm{j}, \mathrm{t}}+£_{\mathrm{j}, \mathrm{t}}$

where,

$R E T_{j, t}=$ return of the company $j$ in the year $t$,

$E_{j, t}=$ earnings before abnormal accruals of the company $j$ in the year $t$,

$\Lambda E_{j, t}=$ the changes in the earnings before abnormal accruals in comparison to those of the previous year,

$\beta_{0,1,2}=$ the parameters of the model,

$£_{j, t}=$ error of the model

Model of Timeliness:

$E_{j, t}=\beta_{0, j}+\beta_{1, j} N E G_{j, t}+\beta_{2 j} R E T_{j, t}+\beta_{3, j} N E G_{j, t} \times R E T_{j, t}+£_{j, t}$

where,

$E_{j, t}=$ earnings before abnormal accruals of the company $j$ in the year $t$,

$R E T_{j, t}=$ return of the company $j$ in the year $t$,

$N E G_{j, t}=$ negative return index, which is equal to zero if $\mathrm{RET}<0$, otherwise equal to zero,

$\beta_{2, j}=$ the coefficient of positive returns on stock (economic gains or good news),

$\beta_{3, j}=$ the coefficient of negative returns on stock (economic losses or bad news),

$\beta_{0,1,2}=$ the parameters of the model,

$£_{j, t}=$ error of the model.

Model of Reliability

$\mathrm{TA}_{\mathrm{it}}=\beta_{1} \mathrm{~A}_{\mathrm{it}-1}+\beta 2\left(\Delta \mathrm{REV}\right.$ it $\left.-\Delta \mathrm{REC}_{\mathrm{it}}\right)+\beta 3 \mathrm{PPE}_{\mathrm{it}}+£_{\mathrm{j}, \mathrm{t}}$

where,

$T A_{i t}=$ the total accruals of the company $i$ for the year $t$,

$\mathrm{A}_{\mathrm{it}-1}=$ the total assets of the company $i$ for the year $t-1$,

$\Delta \mathrm{REV}_{\mathrm{it}}=$ the difference of incomes of the company $i$ for the years $t$ and $t-1$,

$\triangle \mathrm{REC}_{\mathrm{it}}=$ the difference of the claims of the company $i$ for the years $t$ and $t-1$,

$\mathrm{PPE}_{\mathrm{it}}=$ the gross value of the machineries and equipments of the company $i$ in the year $t$,

$\beta_{1}, \beta_{2}, \beta_{3}=$ the parameters of the model;

$£_{\mathrm{j}, \mathrm{t}}=$ error of the model

\subsection{Application Software}

To test the hypotheses of this research by multivariate regression inferentially, SPSS program and Excel application have been used.

\section{Results}

In the Table 1, the values of the central indices including mean, median, and dispersion indices including standard deviation, Kurtosis, and Skewness of the variables have been provided. This fact that the mean is greater than the median indicates the presence of high values among the data that affects mean values. In such Xcases, the skew is on the left side, and in some variables, means and medians are to some extent similar to each other, and this shows a symmetric distribution of the variables. 
Table 1

Description of Variables

\begin{tabular}{ccccc}
\hline Statistical Indices & TL & REL & Re & Con \\
\hline Number of Observations & 94 & 94 & 94 & 94 \\
Mean & 0.3437 & 0.4123 & 0.4457 & 0.4103 \\
Median & 0.26 & 0.4457 & 0.48 & 0.36 \\
Standard Deviation & 0.235 & 0.4103 & 0.2468 & 0.2341 \\
Variance & 0.055 & 0.26 & 0.061 & 0.055 \\
Skewness & 0.568 & 0.41 & -0.081 & 0.433 \\
Kurtosis & -0.944 & 0.48 & -1.296 & -0.912 \\
\hline Total & 200.02 & 0.36 & 259.38 & 238.79 \\
\hline
\end{tabular}

\subsection{Analysis of Presuppositions}

For the application of regression model, it is required to test the presuppositions of this model. For this purpose, Kolmogorov - Smirnov and Durbin - Watson collinearity tests have been carried out.

The results of Kolmogorov - Smirnov test have been provided in the following table:

Table 2

Kolmogorov -Smirnov Test Results for the Normality of Data

\begin{tabular}{ccccccccc}
\hline Indices & Number & \multicolumn{2}{c}{ Normal Parameters } & \multicolumn{3}{c}{ Maximum Deviation } & Kolmogorov - & $\begin{array}{c}\text { Significance } \\
\text { Level }\end{array}$ \\
\cline { 3 - 6 } & & Mean & $\begin{array}{c}\text { Standard } \\
\text { Deviation }\end{array}$ & $\begin{array}{c}\text { Absolute } \\
\text { Value }\end{array}$ & Positive & Negative & & \\
\hline TL & 94 & 0.3564 & 0.24 & 0.242 & 0.242 & -0.123 & 1.836 & 0.226 \\
REL & 94 & 0.4461 & 0.2581 & 0.211 & 0.211 & -0.182 & 1.086 & 0.164 \\
Re & 94 & 0.3462 & 0.3353 & 0.212 & 0.212 & -0.205 & 1.117 & 0.312 \\
Con & 94 & 0.3436 & 0.1896 & 0.175 & 0.175 & -0.14 & 1.231 & 0.257 \\
\hline
\end{tabular}

Considering the values set forth in the above Table 2, the results of the test, as well as the values stipulated in the columns of Significance level, and Kolmogorov- Smirnov, we can conclude that the data of this research are normal. To test the linearity of the relations, correlation test is applied, and this analysis is a statistical tool to determine the type and degree of the relation existing between one quantitative variable and another quantitative one. Correlation coefficient is a criteria used to calculate the correlation between two variables. The coefficient that varies between -1 and 1 , represents the intensity and (direct or inverse) direction of the relation. The correlation coefficient equal to zero indicates that there is no relation between variables. The correlation between variables expressed in form of null and alternative hypotheses have been provided in the following:

$\mathrm{H}_{0}=\rho=0$ variables are independent linearly

$\mathrm{H}_{1}=\rho \neq 0$ variables are correlated linearly

Table 3

Correlation between Independent Variables

\begin{tabular}{cccc}
\hline Variables & TL & REL & Re \\
\hline TL & 1 & 0.04 & -0.033 \\
& & 0.038 & 0.044 \\
REL & 0.04 & 1 & -0.027 \\
& 0.038 & & 0.019 \\
Re & -0.033 & -0.027 & 1 \\
& 0.044 & 0.019 & \\
\hline
\end{tabular}

Note: the values of the first row represent Pearson correlation coefficient and the values of the second row stand for significance level. 
Co linearity is a property showing that one independent variable is a linear function of other independent variables. If the collinearity in a regression equation is high, this means that there is a high correlation between variables. Despite the high value of $\mathrm{R}$, it is possible that the model is not of high reliability. In other words, although the model seems appropriate, its independent variables are not of significance. In the Table 4, the results of the collinearity test of the independent variables have been provided.

Table 4

Co linearity Test of the Independent Variable of Research

\begin{tabular}{ccccc}
\hline Independent Variables & Model & Dimension & Eigen Values & Condition Index \\
\hline First & 1 & 1 & 0.476 & 1.126 \\
Second & 2 & 1 & 0.649 & 3.867 \\
Third & 3 & 1 & 0.562 & 6.326 \\
\hline
\end{tabular}

As stipulated in the Table 4, the Eigen values vary between zero and one, and this indicates the probability of internal correlation of forecasts. Moreover, the value of condition index is lower than 15. This value shows that there is no collinearity between independent variables.

\subsection{The Analysis of the Relation of Variables}

In this research, multivariate regression has been used to study the effects of the independent variables on the dependent ones. In the following, the results of the regression test of the hypotheses are provided.

The Model of the Relation between the Relevance of the Financial Information of Companies and the Amounts of Loans and Bank Contracts

The model is as follows:

$R E T_{j, t}=\beta_{0, j}+\beta_{1, j}+E_{j, t}+\beta_{2, j} \Lambda E_{j, t}+£_{j, t}$

Table 5

Analysis of Variance (ANOVA) of the Linear Regression

\begin{tabular}{cccccc}
\hline Model & $\begin{array}{c}\text { Total } \\
\text { Variance }\end{array}$ & $\begin{array}{c}\text { Degree of } \\
\text { Freedom }\end{array}$ & $\begin{array}{c}\text { Mean } \\
\text { Variance }\end{array}$ & $\begin{array}{c}\text { Probability } \\
\text { Value F }\end{array}$ & Significance Level \\
\hline Regression & 0.136 & 1 & 0.136 & 0.316 & 0.041 \\
Residual & 34.112 & 93 & 0.203 & & \\
Total & 34.248 & 94 & & & \\
\hline
\end{tabular}

As the value of significance level set forth in the above Table 5 is equal to 0.041 and lower than 0.05 , therefore alternative hypothesis is not rejected. This means that this model is of significance at the confidence level of 95 percent.

Table 6

Multivariate Correlation Coefficient, Coefficient of Determination

\begin{tabular}{ccccc}
\hline Model & $\begin{array}{c}\text { Coefficient of } \\
\text { Correlation }\end{array}$ & $\begin{array}{c}\text { Coefficient of } \\
\text { Determination }\end{array}$ & $\begin{array}{c}\text { Adjusted Coefficient } \\
\text { of Determination }\end{array}$ & $\begin{array}{c}\text { Durbin }- \text { Watson } \\
\text { Statistic }\end{array}$ \\
\hline 1 & 0.047 & 0.863 & 0.841 & 1.625 \\
\hline
\end{tabular}

In the Table 6 , the values of the coefficient of correlation and coefficient of determination are equal to 0.047 and 0.863 respectively. This change in the dependent variable is explained by the independent variable. The value of Durbin - Watson statistic equal to 1.625 indicates that there is no correlation between errors. In the following table, the general analysis of the first model has been provided. 
Table 7

The Analysis of the First Model

Statistical Model: Multivariate Linear Regression Model

Number of Companies: 94 Variable Input Method: Enter Confidence Level: $95 \%$ Error Level: $5 \%$

Significance of the Whole Model in Durbin - Watson R Square Adjusted R
ANOVA Square

\begin{tabular}{|c|c|c|c|c|}
\hline F Statistic & Sig. & \multirow[b]{2}{*}{1.625} & & \\
\hline 0.316 & 0.041 & & 0.862 & 0.841 \\
\hline \multicolumn{2}{|c|}{ Significance of each Variable } & Beta & \multicolumn{2}{|c|}{ Independent Variable } \\
\hline Statistic $\mathrm{t}$ & Sig. & & & \\
\hline 0.412 & 0.037 & 0.403 & & \\
\hline
\end{tabular}

As stipulated in the Table 7, the relation between the relevance of the financial information of companies and the amount of loans and bank contracts in 94 companies has been studied statistically using multivariate linear regression.

The value of Durbin - Watson test, which is equal to 1.625 , shows that there is no correlation between errors. The coefficient of determination equal to 0.863 shows that 0.863 of the changes in the amounts of loans and bank contracts (dependent variable) can be explained by the changes in the independent variable (i.e. the relevance of the financial information of companies), and other changes in the amounts of loans and bank contracts by other factors. Thus, it can be concluded that the independent variable affects dependent variables. On the other hand, the value of the significance level in the ANOVA column, which is less than $5 \%$, shows that the whole model is significant. Moreover, the significance level of the independent variable, which is less than $5 \%$, indicates that the whole model is significant too. As a result, H0 is rejected, and H1 is confirmed. The model is as follows:

$$
E_{j, t}=\beta_{0, j}+\beta_{1, j} N E G_{j, t}+\beta_{2, j} R E T_{j, t}+\beta_{3, j} N E G_{j, t} \times R E T_{j, t}+£_{j, t}
$$

Table 8

Analysis of Variance (ANOVA) of the Linear Regression

\begin{tabular}{cccccc}
\hline Model & $\begin{array}{c}\text { Total } \\
\text { Variance }\end{array}$ & $\begin{array}{c}\text { Degree of } \\
\text { Freedom }\end{array}$ & $\begin{array}{c}\text { Mean } \\
\text { Variance }\end{array}$ & $\begin{array}{c}\text { Probability } \\
\text { Value F }\end{array}$ & Significance Level \\
\hline Regression & 0.623 & 1 & 0.223 & 0.460 & 0.034 \\
Residual & 23.162 & 93 & 0.187 & & \\
Total & 23.785 & 94 & & & \\
\hline
\end{tabular}

As the value of significance level set forth in the above Table 8 is equal to 0.043 and lower than 0.05 , therefore alternative hypothesis is not rejected. This means that this model is of significance at the confidence level of 95 percent.

Table 9

Multivariate Correlation Coefficient

\begin{tabular}{ccccc}
\hline Model & $\begin{array}{c}\text { Coefficient of } \\
\text { Correlation }\end{array}$ & $\begin{array}{c}\text { Coefficient of } \\
\text { Determination }\end{array}$ & $\begin{array}{c}\text { Adjusted Coefficient } \\
\text { of Determination }\end{array}$ & $\begin{array}{c}\text { Durbin - Watson } \\
\text { Statistic }\end{array}$ \\
\hline 1 & 0.032 & 0.867 & 0.816 & 1.696 \\
\hline
\end{tabular}

According to the results of Table 9, the values of the coefficient of correlation and coefficient of determination are equal to 0.032 and 0.867 respectively, and this means that such a change in the dependent variable is explained by the independent variable. The value of Durbin - Watson statistic equal to 1.696 indicates that there is no correlation between errors. In the following table, the general analysis of the second model is provided. As stipulated in the Table 10, the relation between the 
timeliness of financial information of companies, amount of loans and bank contracts in 94 companies has been studied statistically using multivariate linear regression.

Table 10

The Analysis of the Second Model

\begin{tabular}{|c|c|c|c|c|}
\hline \multicolumn{2}{|c|}{$\begin{array}{c}\text { Significance of the Whole Model in } \\
\text { ANOVA }\end{array}$} & \multirow[t]{2}{*}{ Durbin - Watson } & \multirow[t]{2}{*}{ R Square } & \multirow[t]{2}{*}{$\begin{array}{l}\text { Adjusted R } \\
\text { Square }\end{array}$} \\
\hline F Statistic & Sig. & & & \\
\hline 0.460 & 0.034 & 1.696 & 0.867 & 0.816 \\
\hline \multicolumn{2}{|c|}{ Significance of each Variable } & Beta & \multirow{2}{*}{\multicolumn{2}{|c|}{ Independent Variable }} \\
\hline Statistic t & Sig. & & & \\
\hline 0.047 & 0.018 & 0.119 & & \\
\hline
\end{tabular}

The value of Durbin - Watson test, which is equal to 1.696 , shows that there is no correlation between errors. The coefficient of determination equal to 0.867 shows that 0.867 of the changes in the amounts of loans and bank contracts (dependent variable) can be explained by the changes in the independent variable (i.e. the timeliness of the financial information of companies), and other changes in the amounts of loans and bank contracts by other factors. Thus, it can be concluded that the independent variable affects dependent variables.

On the other hand, the value of the significance level in the ANOVA column, which is less than $5 \%$, shows that the whole model is significant. Moreover, the significance level of the independent variable, which is less than $5 \%$, indicates that the whole model is significant too. As a result, $\mathrm{H}_{0}$ is rejected, and $\mathrm{H}_{1}$ is confirmed.

The Model of the Relation between the Reliability of the Financial Information of Companies, Amounts of Loans, and Bank Contracts

The model is as follows:

$\mathrm{TA}_{\mathrm{it}}=\beta_{1} \mathrm{~A}_{i t-1}+\beta_{2} \Delta \mathrm{REV}_{\mathrm{it}}-\Delta \mathrm{REC}_{\mathrm{it}}+\beta_{3} \mathrm{PPE}_{\mathrm{it}}+£_{\mathrm{j}, \mathrm{t}}$

Table 11

Analysis of Variance (ANOVA) of the Linear Regression

\begin{tabular}{cccccc}
\hline Model & $\begin{array}{c}\text { Total } \\
\text { Variance }\end{array}$ & $\begin{array}{c}\text { Degree of } \\
\text { Freedom }\end{array}$ & $\begin{array}{c}\text { Mean } \\
\text { Variance }\end{array}$ & $\begin{array}{c}\text { Probability } \\
\text { Value F }\end{array}$ & Significance Level \\
\hline Regression & 0.414 & 1 & 0.414 & 0.384 & 0.023 \\
Residual & 37.324 & 93 & 0.289 & & \\
Total & 37.738 & 94 & & & \\
\hline
\end{tabular}

As the value of significance level set forth in the above table (11) is equal to 0.023 and lower than 0.05 , therefore alternative hypothesis is not rejected. This means that this model is of significance at the confidence level of 95 percent.

Table 12

Multivariate Correlation Coefficient, Coefficient of Determination

\begin{tabular}{ccccc}
\hline Model & $\begin{array}{c}\text { Coefficient of } \\
\text { Correlation }\end{array}$ & $\begin{array}{c}\text { Coefficient of } \\
\text { Determination }\end{array}$ & $\begin{array}{c}\text { Adjusted Coefficient } \\
\text { of Determination }\end{array}$ & $\begin{array}{c}\text { Durbin - Watson } \\
\text { Statistic }\end{array}$ \\
\hline 1 & 0.026 & 0.894 & 0.836 & 1.624 \\
\hline
\end{tabular}

In the table (12), the values of the coefficient of correlation and coefficient of determination are equal to 0.026 and 0.894 respectively, and this means that such a change in the dependent variable is explained by the independent variable. The value of Durbin - Watson statistic equal to 1.624 
indicates that there is no correlation between errors. In the following table, the general analysis of the third model is provided.

\section{Table 13}

The Analysis of the third Model

\begin{tabular}{ccccc}
\hline \multicolumn{2}{c}{\begin{tabular}{c} 
Statistical Model: Multivariate Linear Regression Model \\
\multicolumn{2}{c}{ Variable Input Method: Enter }
\end{tabular}} & $\begin{array}{c}\text { Number of Companies: } 94 \\
\text { Confidence Level: } 95 \%\end{array}$ \\
$\begin{array}{c}\text { Significance of the Whole Model in } \\
\text { ANOVA }\end{array}$ & $\begin{array}{c}\text { Durbin - Watson } \\
\text { R Square }\end{array}$ & $\begin{array}{c}\text { Adjusted R } \\
\text { Square }\end{array}$ \\
F Statistic & Sig. & & & 0.836 \\
\hline 0.384 & 0.023 & 1.624 & 0.894 & Independent Variable \\
$\begin{array}{c}\text { Significance of each Variable } \\
\text { Statistic t }\end{array}$ & Sig. & Beta & \multicolumn{2}{c}{ Re } \\
0.987 & 0.047 & 0.062 & \multicolumn{2}{c}{} \\
\hline
\end{tabular}

As stipulated in the Table 13, the relationship between the reliability of financial information of companies, amount of loans and bank contracts in 94 companies has been studied statistically using multivariate linear regression. The value of Durbin - Watson test, which is equal to 1.624, shows that there is no correlation between errors. The coefficient of determination equal to 0.894 shows that 0.894 of the changes in the amounts of loans and bank contracts (dependent variable) can be explained by the changes in the independent variable (i.e. the reliability of the financial information of companies), and other changes in the amounts of loans and bank contracts by other factors. Thus, it can be concluded that the independent variable affects dependent variables.

Moreover, the significance level of the independent variable, which is less than $5 \%$, indicates the direct and significant effect on the amounts of loans and bank contracts. On the other hand, the value of the significance level in the ANOVA column, which is less than 5\% shows that the whole model is significant. As a result, it can be concluded that the independent variable has effects on the dependent variable significantly. Therefore, $\mathrm{H}_{0}$ is rejected, and $\mathrm{H}_{1}$ is confirmed.

\section{Conclusion}

The hypotheses of this research have been tested using the information collected and analyzed for this research. The main hypothesis has three sub-hypotheses with three independent variables, which affect all three dependent variables as per tests conducted in the previous sections. The findings show that there is a relationship between the relevance, timeliness, and reliability of the financial information of companies, and the amounts of loans and bank contracts. According to the studies and researches, if the quality components of financial information (including relevance, timeliness, and reliability) are observed by companies, supervision costs spent by banks are reduced, interest rate is adjusted better, no higher debt is imposed on companies, a strong relation is established between companies and banks, companies grows and develops more using the facilities borrowed by banks, and finally it leads to the economic upturn of country.

\section{References}

Asquith, P., Beatty, A., \& Weber, J. (2005). Performance pricing in bank debt contracts. Journal of Accounting and Economics, 40(1), 101-128.

Altman, E. I. (1968). Financial ratios, discriminant analysis and the prediction of corporate bankruptcy. The journal of finance, 23(4), 589-609.

Ashbaugh-Skaife, H., Collins, D. W., Kinney Jr, W. R., \& LaFond, R. (2008). The effect of SOX internal control deficiencies and their remediation on accrual quality. The Accounting Review, 83(1), 217-250. 
Beatty, A., \& Weber, J. (2003). The effects of debt contracting on voluntary accounting method changes. The Accounting Review, 78(1), 119-142.

Chaney, P. K., Faccio, M., \& Parsley, D. (2011). The quality of accounting information in politically connected firms. Journal of Accounting and Economics, 51(1), 58-76.

Jiang, B. (2009). An empirical study on information content of accounting earnings and cash flow. Business school, Central South University, Changsha 410083, China.

Kohlbeck, M. (2008). An analysis of recent events on the perceived reliability of fair value measures in the banking industry. Available at SSRN 1117728.

Kousenidis, D. V., Ladas, A. C., \& Negakis, C. I. (2009). Value relevance of conservative and nonconservative accounting information. The International Journal of Accounting, 44(3), 219-238.

Manso, G., Strulovici, B., \& Tchistyi, A. (2010). Performance-sensitive debt.Review of Financial Studies, 23(5), 1819-1854.

Sufi, A. (2007). Information asymmetry and financing arrangements: Evidence from syndicated loans. The Journal of Finance, 62(2), 629-668.

Watts, R. L. (2003). Conservatism in accounting part I: Explanations and implications. Accounting horizons, 17(3), 207-221.

Wittenberg-Moerman, R. (2008). The role of information asymmetry and financial reporting quality in debt trading: Evidence from the secondary loan market. Journal of Accounting and Economics, 46(2), 240-260. 